\title{
Effect of modified atmosphere packaging and edible films on the quality of carp fish patties
}

\begin{abstract}
This study was performed to determine the effect of different concentrations of modified atmosphere packaged (MAP) from $\mathrm{Co}_{2}, \mathrm{~N}_{2}$ and $\mathrm{O}_{2}$ at $\left(100 \% \mathrm{Co}_{2}\right),\left(70 \% \mathrm{Co}_{2} / 20 \% \mathrm{~N}_{2} / 10\right.$ $\left.\% \mathrm{O}_{2}\right)$ and $\left(50 \% \mathrm{CO}_{2} / 50 \% \mathrm{~N}_{2}\right)$ and edible coating soy protein plus essential oil on quality attributes and shelf- life of carp fish patties. All products were stored at $\left(4 \pm 1^{\circ} \mathrm{C}\right)$ for 27 days and the quality parameters such as total volatile basic nitrogen (TVB-N), trimethylamine nitrogen (TMA-N), thiobarbituric acid (TBA), Total bacterial counts (TBC), psychrophilic bacteria count (Psy) and molds and yeasts (M\&Y) were determined . Their effect on microbial changes of product throughout storage period is highly depend on type gas internal package atmosphere appropriate gas composition, storage there was a decrease in microbial load in both treatments under (MAP) as compared to air control. The levels of decrease in chemical and microbial load in the samples from both of the packaging methods were under the (MAP) and edible coating were related good quality and best treatment is $\left(70 \% \mathrm{Co}_{2} / 20 \% \mathrm{~N}_{2} / 10 \% \mathrm{O}_{2}\right)$ at 27 days of storage followed by treatment $\left(50 \% \mathrm{CO}_{2}\right.$ $/ 50 \% \mathrm{~N}_{2}$ ) at 24days while edible coating at 18days. On the level of fatty oxidation and sensory evaluation determined the shelf life of (MAP( and edible coating. Carp fish patties were high acceptability for panelists. Besides, there were significant values in appearance between patties and the higher significant differences in taste of other ones. The mean scores of flavor and acceptability were significantly higher between all products as well as in texture patty products.
\end{abstract}

Keywords: carp fish patties, modified atmosphere packaging, edible coating
Volume 8 Issue | - 2018

\author{
Hosam EL Din, ' Aboul Anean, ${ }^{2}$ Nagla El \\ -Senousi, ${ }^{2}$ Safwat Abdel Ghfour ${ }^{3}$ \\ 'Food Engineering and Packaging Department, Food Technology \\ Research Institute, Agricultural Research Center, Egypt \\ ${ }^{2}$ Meat and Fish Technology Department, Food Technology \\ Research Institute, Agricultural Research Center, Egypt \\ ${ }^{3}$ Fish Processing Technology Lab, National Institute of \\ Oceanography and Fisheries (NIOF), Egypt \\ ${ }^{4}$ Regional Center for Food \& Feed, Agricultural Research Center, \\ Egypt
}

\begin{abstract}
Correspondence: Hosam EL Din, Food Engineering and Packaging Department, Food Technology Research Institute, Agricultural Research Center, Giza, Egypt, Tel 0 I I I2667765,
\end{abstract} Email hosam.ftri@yahoo.com

Received: December 18, 2017| Published: January II, 2018
Abbreviations: MAP, modified atmosphere packaged; TVB-N, total volatile basic nitrogen; TMA-N, trimethylamine nitrogen; TBA, thiobarbituric acid; TBC, total bacterial counts; PSY, psychrophilic bacteria count; $M \& Y$, molds and yeasts

\section{Introduction}

Carp silver fish is characterized by mating more than once a year and its growth is very fast as it weighs after one year from 1 to $2.5 \mathrm{~kg}$ after two years and $4 \mathrm{~kg}$ in the third year and up to $15-20 \mathrm{~kg}$ after 5 years and the turning cycle 7 months since hatching and even marketing. It is a good economic source of animal protein as it has the ability to convert weeds and grasses and algae in the environment to a fish protein. Processing of carp silver fish into patties will solve the problem of a reason for its spread is that it is full of spikes and cannot be eaten. It is in the weight of 100-250 gram, such as tilapia, because it is full of thorns and bones. ${ }^{1}$ A preservation method by altering atmospheric environment around a perishable food by substituting with single or a mixture protective gases is known as modified atmosphere packaging (MAP). MAP executes the basic goal of packaging which is to protect the food material in terms of microbiological and physiochemical qualities as well as sensory attributes. MAP products stored in low temperature condition demonstrates an effectual conservation way for shelf life extension and preservation of quality for a range of fresh supplies such as red meat, poultry, fish and fish products Velu et al. ${ }^{2}$

The rate of deterioration during the storage a food product depends on the biochemical compositions of substrates and metabolites in the tissue, the microbial contamination, and the condition of storage. However, the short shelf-life is a limiting factor for these perishable products. Therefore, certain techniques have been applied to extend the shelf-life of fish products and also safety concern should be taken into consideration. Over the lastyears, modified atmosphere packaging (MAP) has received increasing attention as a method of food preservation. ${ }^{3,4}$ Selection of gas composition in MAP is highly depending on the food product desired to be packed. Single or combination of gases contributes to the extension of shelf life based on the acceptable microbial count and organoleptic properties in terms of color, odor and feel of the food which being perceived in the course smell, feels and visual inspection. MAP is inclusive of common gases of oxygen, nitrogen and carbon dioxide. The three main gases used in MAP are $\mathrm{CO}_{2}, \mathrm{O}_{2}$, and $\mathrm{N}_{2}$, either singly or in combination. The first ,Carbon dioxide $\left(\mathrm{CO}_{2}\right)$ is the most important gas in the MAP of foods because of its bacteriostatic and fungi properties. It inhibits the growth of many spoilage bacteria, the degree of inhibition increasing with increasing concentration.

It is particularly effective against aerobic spoilage bacteria, such as Pseudomonas species. The solubility of $\mathrm{CO}_{2}$ increases with decreasing temperature and therefore the antimicrobial activity of $\mathrm{CO}_{2}$ is markedly greater at lower temperatures. This has significant implications for MAP of foods. The high solubility of $\mathrm{CO}_{2}$ in high moisture/high fat foods such as meat, poultry and seafood can result in package collapse owing to the reduction of heads pace volume. High levels of $\mathrm{CO}_{2}$ can also result in increased drip or exudates from flesh foods, and the addition of absorbent pads in the base of the package is used to compensate for this. The second, gas oxygen $\left(\mathrm{O}_{2}\right)$ promotes several types of deteriorative reactions in foods, including fat oxidation, Most of the common spoilage bacteria and fungi require $\mathrm{O}_{2}$ for growth. For these reasons, $\mathrm{O}_{2}$ is either excluded or the level set 
as low as possible. The third, gas nitrogen $\left(N_{2}\right)$ is an inert gas with no odor or taste and a low solubility in water and other food constituents, making it a useful filler gas in MAP to counteract package collapse caused by $\mathrm{CO}_{2}$ dissolving in the food. Nitrogen indirectly influences the micro-organisms in perishable foods by retarding the growth of aerobic spoilage microbes, According to Kaleemullah. ${ }^{5}$

Soy protein isolated (SPI) films present adequate properties to be used as edible packaging, such as very low aroma and oxygen permeability, which makes, Applying an edible coating such as Soy protein based film to sensitive-to-oxygen products for preserving flavor and to improve the water barrier ability, composite films consisting of SPI and lipids have been produced combined SPI with lauric, palmitic, stearic and oleic acid, found to decrease of almost $50 \%$ in water vapor permeability of SPI when the protein was mixed with beeswax and oleic acid. The plasticizing effect of oleic acid was observed that lead to an indirect improvement in the film mechanical properties. ${ }^{6}$

There for the purpose of this work was to study the effect of different concentrations of (MAP) $\left(100 \% \mathrm{Co}_{2}\right),\left(70 \% \mathrm{Co}_{2} / 20 \% \mathrm{~N}_{2} /\right.$ $\left.10 \% \mathrm{O}_{2}\right)$ and $\left(50 \% \mathrm{CO}_{2} / 50 \% \mathrm{~N}_{2}\right)$ and coating with soy protein plus essential oil cumin on quality attributes and shelf- life of carp fish patties during storage.

\section{Material and methods}

\section{Materials}

Fish sample: Fresh silver carp from 15kilograms used as research material were purchased in the morning from the wholesale fish market in Giza, Egypt. Fish were transferred to the laboratory in an ice box within $30 \mathrm{~min}$.

Technological process: The fish samples were beheaded, gutted and washed gently with tap water, then filleted and skinned by hand. The yield of flesh was $53 \%$. The prepared fillets were cut and minced by a kitchen meat mincer using a $3 \mathrm{~mm}$ diameter whole plate.

Carp fish patties: The first batch of minced fish was minced again with other ingredients prepared shaped into patties. The thickness of the patties $1 \mathrm{~cm}^{3}$ and diameter $7 \mathrm{~cm} 3$

Preparation of carp fish patties: $75.0 \%$ fish mince, $9 \%$ vegetable oil, $8 \%$ starch, $2.3 \%$ salt, $0.4 \%$ Sod. Bicarbonate, $0.3 \%$ Polyphosphate, $2.5 \%$ onion, $0.5 \%$ garlic powder and $2 \%$ Spices mix $(42 \%$ Black pepper, $23 \%$ Cumin, $18 \%$ all spices, $2 \%$ Clove, $5 \%$ Coriander, $2 \%$ Cubeb, 2\% Cardamon, 1\% Red pepper, 5\% Ginger).

Packaging with modified atmosphere and edible coating of carp fish patties was divided into five groups

a) The First, Air Control (A).

b) The Second, were coated by coating solution prepared from soy protein isolate plus $1 \mathrm{ml}$ of essential oil cumin by dipping for $1 \mathrm{~min}$ and subsequently air dried (B).

c) The Third, Internal gas: $100 \% \mathrm{CO}_{2}(\mathrm{C})$.

d) The Four, Internal gas mixture: $50 \% \mathrm{CO}_{2} / 50 \% \mathrm{~N}_{2}$ (D).

e) The Five, Internal gas mixture: $70 \% \mathrm{CO}_{2} / 20 \% \mathrm{~N}_{2} / 10 \% \mathrm{O}_{2}$ (E).

All samples were packaged with polyamide /polyethylene, then packaged in the foam tray capacity of each 4-6 patties. All samples were kept after packaging in the refrigerator $\left(4 \pm 1^{\circ} \mathrm{C}\right)$.

\section{Polyamide/polyethylene}

Polyamide and polyethylene were obtained from Tecno-plast Company, Bourge El-Arabe, Cairo.

\section{Coating solution preparation}

$9 \mathrm{~g}$ Soy Protein Isolate and $3 \mathrm{ml}$ glycerol in $100 \mathrm{ml}$ water, $10 \mathrm{~min}$ mixing, $\mathrm{pH}$ to 8.0 using $\mathrm{NaOH}$, heating $80^{\circ} \mathrm{C} / 20 \mathrm{~min}$, cool to $20^{\circ} \mathrm{C}$, add $0.05 \%$ gellan gum and plus $1 \mathrm{ml}$ essential oil cumin. ${ }^{7}$ Soy protein isolate was obtained from (Allied chemical group, A.C.G). $\mathrm{NaOH}$ and Glycerin (P05650, El-Gomhouria Company. Essential oil cumin was obtained from (Across Organics, Belgium).

\section{Gas measurements}

The gas composition inside the packages was measured with a gas analyzer. Modified atmosphere packaged carp fish patties were sealed by a Model Witt Oxybaby headspace Gas anlyzer $\left(\mathrm{O}_{2}, \mathrm{CO}_{2}\right.$, and $\left.\mathrm{N}_{2}\right)$ company sagueny group wittgas stored at $4 \pm 1^{\circ} \mathrm{C}$. Air packaged group was used as a control group. Analyses were done on air, vacuum and modified atmosphere packaged carp fish patties by using three packaging separately. Of course, WITT is certified according to ISO 22000. This international standard specifies a food safety system.

\section{Leakage test}

Test for the leakage of gaseous A polyamide/polyethylene gas barrier of modified atmosphere packaged carp fish by a company wittgas (sagueny group) offers certified high-quality systems for the leak detection of all types of product packages. You can choose between leak detection systems for sample or continuous checksbased on $\mathrm{CO}_{2}, \mathrm{~N}_{2}$ and $\mathrm{O}_{2}$ or as a bubble test.

\section{Physical and chemical analysis}

\section{Determination of total volatile basic nitrogen (TVB- $-\mathbf{N})$}

Total Volatile Base Nitrogen (TVB-N) value was estimated by the semi-micro distillation Procedure. ${ }^{8,9}$ The bases are steam distilled into Standard acid and back-titration with standard alkali.

\section{Determination of trimethylamine nitrogen}

Trimethylamine nitrogen (TMA-N) was determined using the method after appropriate modification: formaldehyde was used to block the primary and secondary amines. ${ }^{8,10}$

\section{Determination of thiobarbituric acid (TBA)}

Thiobarbituric acid (TBA) value of carp fish patties samples was determined colorimetrically by using the method published by. ${ }^{9}$

\section{Microbiological analyses}

Total bacterial counts (TBC), psychrophilic bacteria count (Psy) and molds and yeasts (M\&Y) of carp fish patties samples were determined, according to the procedures described by Vanderzant \& Splittstoesser. ${ }^{11}$ The presence or absence of Salmonella was determined according to the method described by $\mathrm{FAO}^{12}$ using buffered peptone as a pre-enrichment while tetrathionate broth was used as a selective enrichment broth and S-S agar was used as a selective plating media. Staphylococcus was detected by the procedure of US Department of Agriculture. ${ }^{13}$ Coliform group (Tryptone Bile X-glucuronide (TBX) Medium Oxoid CM945) was determined. ${ }^{14,15}$ 


\section{Sensory evaluation}

All samples of patties were sensory evaluated for appearance, flavor, texture and overall acceptability. The panel consisted of ten members and scores were obtained as described by DLG. ${ }^{16}$ The rejection of samples was based on appearing of the putrid smell of samples.

\section{Statistical analysis}

The obtained data were subjected to the proper statistical analysis using the MSTAT statistical software. The mean values were compared using the LSD method at 5\% level version 17.0. The data were tabulated and statistically analyzed using factorial analyses according to the completely randomized design Snedecor \& Cochran. ${ }^{17}$

\section{Results and discussion}

\section{Gas measurements}

The results indicated in the Table 1 the observation that modified atmosphere packaging \& soy protein coating treatment under the atmosphere packaging (Injected and enhanced products) was the highest level after 27days at (D) while the lower level of (E). Efficiency of Carbon dioxide is characterized by the high fat content of solubility property, which works to expel oxygen and replace them, thus reducing the concentration of oxygen in the fatty substances and ability, reduce oxidation processes and improve the overall appearance of the product and separation of slides fish patties. Oxygen activates the growth of aerobic bacteria, but inhibits the growth of non-aerobic bacteria, and oxygen is important for fresh fish. Nitrogen is an inert gas that is not soluble in both water and fat. It is used to replace oxygen in containers. It is also used to capacity, delay oxidation and it also inhibits the growth of air microbial. Also, Nitrogen is an inert gas that is maintained on the package from degradation that may be occurring during handling food products. According to Aly, Kaleemullah \& Hunt et al. ${ }^{5,17,18}$ These gases have the preservative effects on the packed carp fish patties product.

Their effect on microbial changes of product throughout the storage period highly depends on type gas internal package atmosphere and packaging materials, appropriate gas composition, storage Masniyom. ${ }^{4}$ However, it is acknowledged that the respiration of the enclosed food material, biochemical reactions and slow-moving gases in and out of the packaging materials would lead to the changes in a gaseous atmosphere throughout the storage period which can affect the expected shelf life Velu et al. ${ }^{2}$

Table I Gas composition of internal modified atmosphere packaging \& soy protein coating of patties prepared from silver crop fish during storage at $\left(4 \pm I^{\circ} \mathrm{C}\right)$

\begin{tabular}{|c|c|c|c|c|c|}
\hline \multirow{3}{*}{ Storage Period (Days) } & \multicolumn{5}{|l|}{ Treatments } \\
\hline & A & B & C & D & $\mathbf{E}$ \\
\hline & $\mathrm{CO}_{2} \%, \mathrm{~N}_{2} \%, \mathrm{O}_{2} \%$ & $\mathrm{CO}_{2} \%, \mathbf{N}_{2} \%, \mathrm{O}_{2} \%$ & $\mathrm{CO}_{2} \%, \mathrm{~N}_{2} \%, \mathrm{O}_{2} \%$ & $\mathrm{CO}_{2} \%, \mathrm{~N}_{2} \%, \mathrm{O}_{2} \%$ & $\mathrm{CO}_{2} \%, \mathbf{N}_{2} \%, \mathrm{O}_{2} \%$ \\
\hline 0 & $\mathrm{I}, 78.8,20,2$ & $1.8,78,20.2$ & $95.0,3.7,1.0$ & $47.5,48.3,4.2$ & $68.7,18.6,12.7$ \\
\hline 5 & $0.9,78.0,20.4$ & I.75, $78,20.4$ & $93.2,5.1,1.7$ & $45.2,47.9,6.9$ & $67.5,17.0,15.5$ \\
\hline 10 & $0.8,77.0,20$ & $1.60,77.6,20.0$ & $90.1,8.6,1.3$ & $40.8,45.1,14.1$ & $65.3,15.1,19.6$ \\
\hline 15 & Reject & $1.55,76,19.0$ & $85.0,13.8,1.2$ & $38.0,43.5,18.5$ & $63.5,14.3,22.2$ \\
\hline 20 & Reject & Reject & $80.6,18.0,1.4$ & $36.9,42.4,20.7$ & $60.2,13.5,26.3$ \\
\hline 27 & Reject & Reject & $75.8,23.5,1.2$ & $35.7,40.5,23.8$ & $58.6,12.2,29.2$ \\
\hline
\end{tabular}

A, air control; B, edible coating; C:(100\% $\left.\mathrm{Co}_{2}\right) ; \mathrm{D}:\left(50 \% \mathrm{CO}_{2} / 50 \% \mathrm{~N}_{2}\right) ; \mathrm{E}:\left(70 \% \mathrm{Co}_{2} / 20 \% \mathrm{~N}_{2} / 10 \% \mathrm{O}_{2}\right)$

\section{Leakage test}

No detections of gas leakage or bubbles was found from analysis of the tested parameters for the packaging materials used for internal package atmosphere are gas proof with polyamide/polyethylene films for packed carp fish patties products . For instance, recommended gas composition for fish is $\mathrm{CO}_{2} / \mathrm{N}_{2} / \mathrm{O}_{2}: 40 / 30 / 30$, while for and fatty fish is $\mathrm{CO}_{2} / \mathrm{N}_{2}: 40 / 60$ or $\mathrm{CO}_{2} / \mathrm{N}_{2}: 60 / 40$.present the use of various composition of gas in MAP for various fishery products. ${ }^{19}$

\section{Total volatile bases nitrogen (TVB-N)}

The obtained results are recorded in Table 2 that the highest level of TVB-N was in the (A) control treatment 30.00 on 9day of the analysis, while the using the (B) Edible coating was recorded 30.00 until the 18day whereas found that the treatment under modified atmosphere packaging was the highest level after 27day at (D) while the lowest level of TVB-N was treated in both $(\mathrm{C})$ and $(\mathrm{E})$ may be due to The formation of carbonic acid, which inhibits bacterial growth and thus reduces protein degradation. On the other hand found that the main differences among the averages showed that the lowest significant difference between the averages the coefficients during the different storage period, As the same time, the results showed that the best treatment is (D) at 27days of storage followed by treatment (D) at 24days and (E) at 24 and 27days of storage. According to TVB-N values, marinated anchovies under vacuum Packaging and (MAP) conditions were related "good quality" and under the unacceptable limit according to the

In modified atmosphere packaging marinated anchovy samples, the average TVB-N level was reached to an average $22.47 \pm 0.025 \mathrm{mg}$ $\mathrm{N} / 100 \mathrm{~g}$ in the samples of $70 \% \mathrm{CO}_{2} / 30 \%$ and $23.01 \pm 0.02 \mathrm{mg} \mathrm{N} / 100 \mathrm{~g}$ in the samples of $50 \% \mathrm{CO}_{2} / 50 \%$ on the 11 th month of storage at $2 \pm 2^{\circ} \mathrm{C} .{ }^{20}$ This finding was in agreement with those reported by Metin et al. ${ }^{21}$ 


\section{Trimethylamine nitrogen (TMA-N)}

The results indicated in the Table 2 the level of TMA-N in the (A) control treatment 10.07 on day 9 of the analysis while the use of the (B) Edible coating was recorded 9.37 until the 18day while the treatment under the modified atmosphere packaging was the highest level after 27days in (D) while the lower level of TMA-N was (E). The best treatment were (D and E) at 24 and 27 days followed by treatment (C) at 12days from storage. It is well documented that increasing $\mathrm{pH}$ values during storage may be attributed to the production of basic compounds such as ammonia, dimethylamine, trimethylamine as well as other biogenic amines as a result of fish spoilage bacterial action. ${ }^{21}$

Table 2 Effect of modified atmosphere packaging \& soy protein coated on chemical quality attributes of patties prepared from silver crop fish during storage at $\left(4 \pm I^{\circ} \mathrm{C}\right)$

\begin{tabular}{|c|c|c|c|c|c|c|c|c|c|c|}
\hline \multirow{2}{*}{ Treatment } & \multicolumn{10}{|c|}{ Storage Period (Days) } \\
\hline & 0 & 3 & 6 & 9 & 12 & 15 & 18 & 21 & 24 & 27 \\
\hline \multicolumn{11}{|l|}{ TVB-N } \\
\hline A & $12.50^{c}$ & $16.80^{c}$ & $23.60^{\mathrm{b}}$ & $30.00^{\mathrm{a}}$ & Reject & Reject & Reject & Reject & Reject & Reject \\
\hline B & $12.50^{c}$ & $16.20^{c}$ & $23.00^{\mathrm{b}}$ & $26.60^{\mathrm{a}}$ & $28.10^{\mathrm{a}}$ & $29.30^{\mathrm{a}}$ & $30.00^{\mathrm{a}}$ & Reject & Reject & Reject \\
\hline C & $12.20^{c}$ & $14.60^{c}$ & $18.00^{b}$ & $22.70^{\mathrm{b}}$ & $24.40^{\mathrm{a}}$ & $25.50^{\mathrm{a}}$ & $26.80^{\mathrm{a}}$ & $29.20^{\mathrm{a}}$ & $29.60^{\mathrm{a}}$ & $30.00^{\mathrm{a}}$ \\
\hline D & $12.40^{c}$ & $15.10^{c}$ & $18.50^{\mathrm{b}}$ & $21.40^{\mathrm{b}}$ & $25.70^{\mathrm{a}}$ & $26.80^{\mathrm{a}}$ & $28.70^{\mathrm{a}}$ & $29.00^{\mathrm{a}}$ & $29.80^{\mathrm{a}}$ & $30.10^{\mathrm{a}}$ \\
\hline$E$ & $12.30^{c}$ & $14.90^{\circ}$ & $19.40^{\mathrm{b}}$ & $22.60^{\mathrm{b}}$ & $25.70^{\mathrm{a}}$ & $26.50^{\mathrm{a}}$ & $27.90^{\mathrm{a}}$ & $28.50^{\mathrm{a}}$ & $29.60^{\mathrm{a}}$ & $30.00^{\mathrm{a}}$ \\
\hline L.S.D & 5.8437 & & & & & & & & & \\
\hline \multicolumn{11}{|l|}{ TMA-N } \\
\hline A & $5.37^{d}$ & $6.37^{c}$ & $7.87^{\mathrm{b}}$ & $10.07^{a}$ & Reject & Reject & Reject & Reject & Reject & Reject \\
\hline B & $5.57^{d}$ & $6.67^{c}$ & $7.27^{c}$ & $8.17^{b}$ & $8.67^{b}$ & $9.07^{a}$ & $9.37^{a}$ & Reject & Reject & Reject \\
\hline C & $5.17^{d}$ & $5.67^{d}$ & $6.27^{c}$ & $6.57^{c}$ & $6.87^{c}$ & $7.77^{\mathrm{b}}$ & $8.07^{b}$ & $8.67^{b}$ & $9.37^{a}$ & $9.37^{a}$ \\
\hline D & $5.27^{d}$ & $6.07^{d}$ & $6.77^{c}$ & $6.97^{c}$ & $7.57^{b}$ & $7.87^{b}$ & $8.27^{b}$ & $8.87^{a}$ & $9.07^{a}$ & $9.07^{a}$ \\
\hline$E$ & $5.17^{d}$ & $5.87^{d}$ & $6.57^{c}$ & $6.97^{c}$ & $7.57^{\mathrm{b}}$ & $8.07^{b}$ & $8.67^{b}$ & $8.87^{a}$ & $9.17^{\mathrm{a}}$ & $9.17^{\mathrm{a}}$ \\
\hline L.S.D & I.1857 & & & & & & & & & \\
\hline \multicolumn{11}{|l|}{ TBA } \\
\hline A & $.99^{\mathrm{d}}$ & $1.45^{d}$ & $1.45^{\mathrm{d}}$ & $2.59^{\mathrm{b}}$ & Reject & Reject & Reject & Reject & Reject & Reject \\
\hline B & $.94^{\mathrm{d}}$ & $1.36^{\mathrm{d}}$ & $1.36^{\mathrm{d}}$ & $2.17^{b}$ & $2.27^{\mathrm{b}}$ & $2.46^{\mathrm{b}}$ & $2.83^{\mathrm{a}}$ & Reject & Reject & Reject \\
\hline C & $1.08^{\mathrm{d}}$ & $1.65^{d}$ & $1.65^{d}$ & $2.14^{c}$ & $2.43^{b}$ & $2.60^{\mathrm{b}}$ & $2.77^{a}$ & $2.90^{\mathrm{a}}$ & $2.96^{\mathrm{a}}$ & $3.0 \mathrm{I}^{\mathrm{a}}$ \\
\hline D & $.87^{d}$ & $1.05^{d}$ & $1.05^{\mathrm{d}}$ & $1.55^{\mathrm{c}}$ & $1.88^{\mathrm{c}}$ & $1.97^{c}$ & $2.15^{b}$ & $2.55^{\mathrm{b}}$ & $3.15^{\mathrm{a}}$ & $3.23^{\mathrm{a}}$ \\
\hline$E$ & $1.04^{d}$ & $1.48^{\mathrm{d}}$ & $1.48^{\mathrm{d}}$ & $2.10^{c}$ & $2.34^{b}$ & $2.50^{\mathrm{b}}$ & $2.59^{\mathrm{b}}$ & $2.66^{\mathrm{a}}$ & $2.86^{\mathrm{a}}$ & $2.93^{\mathrm{a}}$ \\
\hline L.S.D & 0.5844 & & & & & & & & & \\
\hline
\end{tabular}

A, air control; B, edible coating; C:( $\left.100 \% \mathrm{Co}_{2}\right)$; D:(50\% $\left.\mathrm{CO}_{2} / 50 \% \mathrm{~N}_{2}\right) ; \mathrm{E}:\left(70 \% \mathrm{Co}_{2} / 20 \% \mathrm{~N}_{2} / 10 \% \mathrm{O}_{2}\right)$

TVB-N (mg//00g), TMA-N (mg// 00g),TBA (mg//000g)

Mean treatment and storage period showing the same small letters are not significantly difference $(P \leq 0.05)$.

\section{Thiobarbituric acid (TBA)}

The results indicated in the Table 2 the level of TBA in (A) control treatment 2.59 afterday 9 of the analysis while the use of the (B) Edible coating was recorded 2.83 after 18days while the treatment under the modified atmosphere packaging was the highest level (3.23) after 27days at (D) while the lower level of TBA was (E) was recorded (2.93). The best treatment was (E) at 27days, followed by treatment
(E) at 24 days, followed by (C) at 24 days of storage. In the results of TBA analysis were parallel to sensory analysis, since fat oxidation had intensely progressed. Under MAP conditions, the shelf-life of marinated anchovies was extended up to 4 months for two different gas mixture conditions ( $\left.70 \% \mathrm{CO}_{2} / 30 \% \mathrm{~N}_{2}\right)$ and $\left(50 \% \mathrm{CO}_{2} / 50 \% \mathrm{~N}_{2}\right)$ as compared to vacuum packaging condition ${ }^{22}$ and this finding was in agreement with those reported by Velu et al. ${ }^{2}$ 
Effect of modified atmosphere packaging \& soy protein coating of carp fish patties on microbiological evaluation

The microbiological analysis included, total bacterial count, psychrophilic bacteria, molds \& yeasts count, Salmonella spp, Staphylococcus and Coliform group of modified atmosphere packaging and soy protein coated carp fish kept with different condition during storage refrigerator at $\left(4 \pm 1^{\circ} \mathrm{C}\right)$.

\section{Total bacterial count}

The changes in the total bacterial count of modified atmosphere packaging \& soy protein coated were determined during the storage period (27days) at cold temperature. The obtained results are recorded in Table 3 the results indicated that the counts gradually increased with increasing of storage period in both samples of modified atmosphere packaging and Edible coating. The (B) edible coating treatment indicates higher counts than (C) after 18days. On the other hand The counts reached to (24.79) and $(22.49) \times 10^{2} \mathrm{CFU} / \mathrm{g}$ after 27 days of storage for samples of modified atmosphere packaging in both (D) and $(\mathrm{E})$, as compared with initial counts of $5.99 \times 10^{2}(\mathrm{CFU} / \mathrm{g})$. A great load of bacterial count was characterized (A) control samples to be $(18.49) \times 10^{2}(\mathrm{CFU} / \mathrm{g})$ after 9 days of storage. It was also observed that (C) was the worst treatment after 27 days followed by treatment (D) at 27 days of storage.

Table 3 Effect of modified atmosphere packaging \& soy protein coating on microbiology count of patties prepared from common crop fish during storage at $\left(4 \pm 1^{\circ} \mathrm{C}\right)$

\begin{tabular}{|c|c|c|c|c|c|c|c|c|c|c|}
\hline \multirow{2}{*}{ Treatment } & \multicolumn{10}{|c|}{ Storage period (Days) } \\
\hline & 0 & 3 & 6 & 9 & 12 & 15 & 18 & 21 & 24 & 27 \\
\hline \multicolumn{11}{|l|}{ T.C } \\
\hline A & $5.99^{\mathrm{d}}$ & $10.99^{\mathrm{d}}$ & $12.79^{c}$ & $18.49^{a}$ & Reject & Reject & Reject & Reject & Reject & Reject \\
\hline B & $4.49^{d}$ & $9.99^{d}$ & $11.79^{\circ}$ & $12.59^{c}$ & $14.79^{c}$ & $16.39^{\circ}$ & $18.99^{\mathrm{b}}$ & Reject & Reject & Reject \\
\hline C & $3.24^{\mathrm{d}}$ & $9.19^{d}$ & $11.59^{\circ}$ & $12.89^{c}$ & $13.79^{c}$ & $15.69^{b}$ & $18.59^{\mathrm{b}}$ & $21.49^{b}$ & $23.19^{a}$ & $26.69^{\mathrm{a}}$ \\
\hline D & $3.24^{d}$ & $7.99^{\mathrm{d}}$ & $10.19^{d}$ & $12.59^{c}$ & $13.19^{c}$ & $14.49^{\circ}$ & $16.99^{b}$ & $19.59^{\mathrm{b}}$ & $21.79^{a}$ & $24.79^{\mathrm{a}}$ \\
\hline$E$ & $2.99^{\mathrm{d}}$ & $6.49^{d}$ & $8.89^{d}$ & $10.29^{d}$ & $11.99^{\circ}$ & $13.19^{\circ}$ & $15.49^{\circ}$ & $17.59^{\mathrm{b}}$ & $20.39^{b}$ & $22.49^{\mathrm{a}}$ \\
\hline L.S.D & 5.056 & & & & & & & & & \\
\hline \multicolumn{11}{|l|}{ PSY } \\
\hline A & $2.11^{d}$ & $3.6 \mathrm{I}^{\mathrm{c}}$ & $7.11^{a}$ & $7.8 I^{a}$ & Reject & Reject & Reject & Reject & Reject & Reject \\
\hline B & $1.61^{e}$ & $3.11^{d}$ & $3.6 \mathrm{I}^{\mathrm{c}}$ & $4.1 I^{c}$ & $4.96^{\mathrm{b}}$ & $5.16^{\mathrm{b}}$ & $5.7 I^{b}$ & Reject & Reject & Reject \\
\hline C & $1.61^{e}$ & $2.7 \mathrm{I}^{\mathrm{d}}$ & $3.4 \mathrm{I}^{\mathrm{c}}$ & $3.7 I^{\mathrm{c}}$ & $4.46^{c}$ & $4.8 \mathrm{I}^{\mathrm{b}}$ & $5.56^{\mathrm{b}}$ & $6.46^{\mathrm{a}}$ & $6.90^{\mathrm{a}}$ & $7.56^{\mathrm{a}}$ \\
\hline D & $1.61^{\mathrm{e}}$ & $2.3 \mathrm{I}^{\mathrm{d}}$ & $3.06^{d}$ & $3.56^{\mathrm{c}}$ & $4.01^{\mathrm{c}}$ & $4.56^{c}$ & $5.3 \mathrm{I}^{\mathrm{b}}$ & $6.1 \mathrm{I}^{\mathrm{b}}$ & $6.57^{\mathrm{a}}$ & $7.06^{\mathrm{a}}$ \\
\hline $\mathrm{E}$ & $1.36^{\mathrm{e}}$ & $1.86^{d}$ & $2.5 \mathrm{I}^{\mathrm{d}}$ & $2.6 \mathrm{I}^{\mathrm{d}}$ & $3.31^{c}$ & $\left.3.7\right|^{\mathrm{c}}$ & $4.4 I^{c}$ & $5.0 \mathrm{I}^{\mathrm{b}}$ & $2.8 \mathrm{I}^{\mathrm{d}}$ & $6.56^{\mathrm{a}}$ \\
\hline L.S.D & 1.5414 & & & & & & & & & \\
\hline \multicolumn{11}{|l|}{$M \& Y$} \\
\hline A & $3.5 \mathrm{I}^{\mathrm{d}}$ & $5.5 \mathrm{I}^{\mathrm{d}}$ & $8.5 \mathrm{I}^{\mathrm{b}}$ & $|3.3|^{a}$ & Reject & Reject & Reject & Reject & Reject & Reject \\
\hline B & $2.5 \mathrm{I}^{\mathrm{e}}$ & $5.0 \mathrm{I}^{\mathrm{d}}$ & $6.01^{c}$ & $6.81^{c}$ & $7.4 I^{c}$ & $8.7 I^{b}$ & $9.4 \mathrm{I}^{\mathrm{b}}$ & Reject & Reject & Reject \\
\hline C & $2.26^{\mathrm{e}}$ & $4.6 \mathrm{I}^{\mathrm{d}}$ & $5.91^{\mathrm{c}}$ & $6.5 \mathrm{I}^{\mathrm{c}}$ & $6.81^{c}$ & $8.0 \mathrm{I}^{\mathrm{b}}$ & $9.3 \mathrm{I}^{\mathrm{b}}$ & $10.7 I^{b}$ & $|1.5|^{\mathrm{a}}$ & $|3.4|^{\mathrm{a}}$ \\
\hline D & $2.26^{\mathrm{e}}$ & $4.0 \mathrm{I}^{\mathrm{d}}$ & $5.2 \mathrm{I}^{\mathrm{d}}$ & $6.31^{\mathrm{c}}$ & $6.61^{\mathrm{c}}$ & $7.31^{c}$ & $8.5 \mathrm{I}^{\mathrm{b}}$ & $9.8 I^{b}$ & $10.6 \mathrm{I}^{\mathrm{b}}$ & $|2.4|^{\mathrm{a}}$ \\
\hline $\mathrm{E}$ & $2.01^{e}$ & $3.2 \mathrm{I}^{\mathrm{d}}$ & $4.4 \mathrm{I}^{\mathrm{d}}$ & $5.2 \mathrm{I}^{\mathrm{P}}$ & $6.31^{c}$ & $6.6 \mathrm{I}^{\mathrm{c}}$ & $7.8 I^{c}$ & $8.5 \mathrm{I}^{\mathrm{b}}$ & $10.01^{b}$ & $\left.11.2\right|^{\mathrm{a}}$ \\
\hline L.S.D & $2.566 \mathrm{I}$ & & & & & & & & & \\
\hline
\end{tabular}

A, air control; B, edible coating; C: $\left(100 \% \mathrm{Co}_{2}\right)$; D: $\left(50 \% \mathrm{CO}_{2} / 50 \% \mathrm{~N}_{2}\right)$; E: $\left(70 \% \mathrm{Co}_{2} / 20 \% \mathrm{~N}_{2} / 10 \% \mathrm{O}_{2}\right)$

Mean treatment and storage period showing the same small letters are not significantly difference $(P \leq 0.05)$

TC, total bacterial count (CFUxI0-2/ g); M\&Y, total molds and yeast count (CFUxI0-2/ g); PSY, psychrophilic bacterial count (CFU $\left.x I 0^{-2} / \mathrm{g}\right)$.

Citation: Hosam Aboul-Anean, Naglaa A El -Senousi, Ghfour SA. Effect of modified atmosphere packaging and edible films on the quality of carp fish patties. J Nutr Health Food Eng. 2018;8(I):14-22. DOI: 10.15406/jnhfe.2018.08.0025। 


\section{Psychrophilic bacteria}

The changes in psychrophilic bacteria count of modified atmosphere packaging \& soy protein coated were determined in the Table 3 during storage period (27days) at cold temperature. The results indicated that the counts gradually increased with increasing of storage period at cold temperature in both samples of modified atmosphere packaging and edible coating. The (B) treatment indicates higher counts than $(\mathrm{C})$ after 18days. On the other hand the counts reached to $(7.56)$ and $(7.06) \times 10^{2} \mathrm{CFU} / \mathrm{g}$ after 27 days of storage for samples of modified atmosphere packaging in both (C) and (D), as compared with initial counts $2.11 \times 10^{2}(\mathrm{CFU} / \mathrm{g})$ a great load of bacterial count was characterized (A) control samples to be $(7.81) \times 10^{2}(\mathrm{CFU} / \mathrm{g})$ after 9days of storage this is the worst treatment followed by treatment $(\mathrm{E})$ at 27 days of storage. Lauzon et al., ${ }^{23}$ indicated those psychrotrophic temperatures of -2 and $-3.6^{\circ} \mathrm{C}$. The Sensory shelf life of cod fillets has been extended in MAP combined with super chilling condition than super chilled air samples. Base on microbiological result, trout has the longest shelf life of 37days in MAP packages of higher composition of $\mathrm{CO}_{2}$ compared to only 33 days shelf life in vacuum packaged samples. Similarly, extended shelf life has been observed in MAP samples of sixdays than in air stored maatjes herring samples. It has been reported MAP inclusive of certain composition $\mathrm{Co}_{2}$ and $\mathrm{O}_{2}$ $\left(\mathrm{O}_{2} / \mathrm{CO}_{2}: 50 / 50\right.$ or $\left.\mathrm{O}_{2} / \mathrm{CO}_{2}: 70 / 30\right)$ retain the color of meat samples for extended periods. ${ }^{24}$

\section{Molds and yeasts count}

The changes in molds and yeast count of modified atmosphere packaging \& soy protein coated were determined during the storage period (27days) at cold temperature. The obtained results are recorded in Table 3. The results indicated that the counts gradually increased with increasing of storage period at cold temperature in both samples of modified atmosphere packaging and edible coating. The (B) treatment indicates higher counts than $(\mathrm{C})$ after 18days .On the other hand The counts reached to (13.41) and $(12.41) \times 10^{2} \mathrm{CFU} / \mathrm{g}$ after 27 days of storage for samples of modified atmosphere packaging in both $(\mathrm{C})$ and $(\mathrm{D})$, as compared with initial counts $3.51 \times 10^{2}(\mathrm{CFU} / \mathrm{g})$ a great load of bacterial count was characterized (A) control samples to be $(13.31) \times 10^{2}(\mathrm{CFU} / \mathrm{g})$ after 9days of storage this is the worst treatment followed by treatment (C) and (D) after 27 days of storage.

The microbiological analysis results of (MAP) by different gas mixtures $\left(70 \% \mathrm{CO}_{2} 30 \% \mathrm{~N}_{2}, 50 \% \mathrm{CO}_{2} / 50 \% \mathrm{~N}^{2}\right)$. The results of total Aerobic Hemophilic Bacteria count indicated that MAP was more effective than under vacuum for decreasing the microbial load in marinated anchovy sample storage. $\mathrm{CO}_{2}$ is the major bacteriostatic factor of MAP. $\mathrm{CO}_{2}$ may extend the lag phase and /or generation time in the logarithmic phase of growth, thus inhibiting microbial growth. The effect increases as the temperature decreases, due to the increasing solubility participating in $\mathrm{CO}_{2}$ Uğur Günşen et al. ${ }^{22}$ This anti-microbial behavior was reported for $\mathrm{CO}_{2}$ content up to $30 \% .{ }^{25}$ Similar results have also been observed in studied the consequences of modified atmosphere on microbial changes of rainbow trout fillets. It was found that MAP of $\mathrm{CO}_{2}: 100 \%, \mathrm{CO}_{2} / \mathrm{N}_{2} / \mathrm{O}_{2}: 90 / 7.5 / 2.5$ and $\mathrm{CO}_{2} / \mathrm{N}_{2} / \mathrm{O}_{2}: 40 / 30 / 30$ each with a certain level of inhibition on aerobic bacterial counts. They revealed that MAP of $100 \% \mathrm{CO}_{2}$ exhibited the greatest inhibitory effect as the count reached $105 \mathrm{CFU} / \mathrm{g}$ on 14days of storage for the hemophilia bacterial count. Arashisar et al., ${ }^{26}$ have noted that the effect of $\mathrm{CO}_{2}: 90 \%$ and $\mathrm{CO}_{2}: 40 \%$ are lower in comparison with $\mathrm{CO}_{2}: 100 \%$. In addition, according to Lopez-
Caballero et al., ${ }^{27}$ comparable to shrimps stored under iced and air condition, $\mathrm{MAP}$ of $\mathrm{CO}_{2} / \mathrm{N}_{2} / \mathrm{O}_{2}: 40 / 30 / 30$ and $\mathrm{CO}_{2} / \mathrm{N}_{2} / \mathrm{O}_{2}: 45 / 50 / 5$ have shown greater inhibition for total bacterial counts, Velu et al. ${ }^{2}$ Results obtained, MAP with composition of $\mathrm{CO}_{2} / \mathrm{N}_{2}: 80 / 20$ attained lowest count for total viable count $7.0 \operatorname{logs} \mathrm{CFU} / \mathrm{g}$ on 15 days of storage which is also similar for vacuum packaging. However control and other MAP conditions reached the microbiological. Reported that this inhibitory effect would be mainly due to high concentration of $\mathrm{CO}_{2}$ as it inhibits growth of aerobic microorganisms. They used gas composition for MAP are as follows: $\mathrm{A}\left(\mathrm{O}_{2} / \mathrm{CO}_{2} / \mathrm{N}_{2}: 0 / 70 / 30\right), \mathrm{B}\left(\mathrm{O}_{2} /\right.$ $\left.\mathrm{CO}_{2} / \mathrm{N}_{2}: 20 / 70 / 10\right), \mathrm{C}\left(\mathrm{O}_{2} / \mathrm{CO}_{2} / \mathrm{N}_{2}: 30 / 60 / 10\right), \mathrm{D}\left(\mathrm{O}_{2} / \mathrm{CO}_{2} / \mathrm{N}_{2}: 40 / 60 / 0\right)$, $\mathrm{E}\left(\mathrm{O}_{2} / \mathrm{CO}_{2} / \mathrm{N}_{2}: 30 / 50 / 20\right)$ and $\mathrm{F}\left(\mathrm{O}_{2} / \mathrm{CO}_{2} / \mathrm{N} 2: 21 / 0 / 79\right)$. In terms of aerobic mesophilic bacteria (AMB), MAP of $\mathrm{B}$ and $\mathrm{E}$ showed greater inhibition compared to the other MAP compositions. AMB of below 1 $\log \mathrm{CFU} / \mathrm{g}$ at 0 days found to be $2.5 \times 106 \operatorname{logs} \mathrm{CFU} / \mathrm{g}$ and $2.2 \times 107 \operatorname{logs}$ $\mathrm{CFU} / \mathrm{g}$, respectively in $\mathrm{B}$ and $\mathrm{E}$ at 9days which is still under the upper acceptability limit. ${ }^{2,28}$

\section{Pathogenic bacteria}

From the results in Table 4, it could be noticed that Salmonella spp, Staphylococcus and Coliform group. Was detected only in air control samples at zero time. However, it was not detected in all samples in both samples of modified atmosphere packaging and edible coating .It was reported that Staphylococcus spp., yeast and could and Coliform group could not be isolated in cold at the end of the storage. The counts of, Staphylococcus-Micrococcus and yeasts-molds were reduced in anchovy marinades produced in different acid-salt concentrations. Similar results were also reported by Uğur Günşen et al. ${ }^{22}$

Table 4 Effect of Gas composition of internal package atmosphere and coated with soy protein on pathogenic bacteria of patties at cold temperature $\left(4 \pm I^{\circ} \mathrm{C}\right)$

\begin{tabular}{lccccc}
\hline Microorganisms & A & B & C & D & E \\
\hline Salmonella spp. & - & - & - & - & - \\
Staphylococcus & - & - & - & - & - \\
Coliform & - & - & - & - & - \\
\hline
\end{tabular}

(+): Positive (Present Bacteria); (-): No Growth (Absent Bacteria).

\section{Sensory properties}

The mean scores of sensory properties (appearance, flavor, texture and overall acceptability) of fast processed carp products are shown in Table 5. This indicated that fast fishery products made from big size silver carp fish patties were high acceptability for panelists. Besides, there were significant values in appearance between the patties and the higher significant differences in taste of other ones. The mean scores of flavor and acceptability were significantly higher $(\mathrm{P} \leq 0.05)$ between all products as well as in texture patties products. The results of the sensory evaluation in Table 5 showed general acceptance on the first day and was fairly equal while the (A) control was rejected after the 9days of storage while the treatment continued with the (B) edible coating till day 18 , whereas the treatment under the modified atmosphere packaging (E) was the best treatment in terms of appearance, taste and cohesive texture as noted that the least in sensory acceptance (C).

The results of the statistical analysis were as follows, appearance the best treatment was at $(\mathrm{B}$ and $\mathrm{D}$ ( in zero time and $(\mathrm{D}$ ( at 3days. The flavor, the best treatment was at (A (in zero time, followed by (B, 
C, D, E) at zero time this means that the characteristic is limited by increasing the storage period .Texture the best treatment was at (B) in Zero Tim followed by (A, C and D) in Zero Time, this means that the characteristic is limited by increasing the storage period. Overall the best treatment was at (A-E) at Zero Tim but at 3days the best treatment was $\mathrm{E}$ followed by $\mathrm{D}$ followed by $\mathrm{A}, \mathrm{B}$ as some. This means that the general acceptance of the product decreases with increasing storage periods. The appearance of the seafood product in vacuum packaging and modified-atmosphere packaging is important because it influences the acceptability of the product to consumers. The appearance of a seafood product can be assessed visually, including pack collapse, production of drip, and discoloration. Organoleptic properties of the product can be assessed by color, odor, flavor and texture. ${ }^{29}$ Statistical comparisons between the results from sensory changes during the storage period showed that there were significant differences in reducing values depended on the storage period $(\mathrm{P}<0.05)$. In addition, it was found that the statistical importance between the values of appearance, odor, flavor and texture were higher than in the othermonths in the samples of vacuum packaging, and gas mixtures $\left(70 \% \mathrm{CO}_{2} / 30 \% \mathrm{~N}_{2}, 50 \% \mathrm{CO}_{2} / 50 \% \mathrm{~N}_{2}\right)$ marinated anchovy, respectively.

Table 5 Effect of modified atmosphere packaging \& soy protein coated on sensory evolution of patties prepared from common crop fish during storage at $\left(4 \pm I^{\circ} \mathrm{C}\right)$

\begin{tabular}{|c|c|c|c|c|c|c|c|c|c|c|}
\hline \multirow{2}{*}{ Treatment } & \multicolumn{10}{|c|}{ Storage period (Days) } \\
\hline & 0 & 3 & 6 & 9 & 12 & 15 & 18 & 21 & 24 & 27 \\
\hline \multicolumn{11}{|l|}{ Appearance } \\
\hline A & $9.317^{\mathrm{a}}$ & $8.700^{\mathrm{a}}$ & $7.500^{\mathrm{b}}$ & $6.200^{c}$ & Reject & Reject & Reject & Reject & Reject & Reject \\
\hline B & $9.433^{\mathrm{a}}$ & $8.967^{a}$ & $8.683^{a}$ & $7.749^{\mathrm{b}}$ & $7.967^{\mathrm{b}}$ & $7.083^{b}$ & $6.306^{\mathrm{b}}$ & Reject & Reject & Reject \\
\hline C & $9.317^{\mathrm{a}}$ & $9.033^{\mathrm{a}}$ & $8.933^{\mathrm{a}}$ & $8.767^{\mathrm{a}}$ & $8.433^{\mathrm{a}}$ & $7.733^{\mathrm{b}}$ & $7.400^{\mathrm{b}}$ & $7.083^{b}$ & $6.967^{\mathrm{b}}$ & $5.933^{c}$ \\
\hline D & $9.500^{\mathrm{a}}$ & $9.400^{\mathrm{a}}$ & $9.051^{a}$ & $8.616^{a}$ & $8.349^{\mathrm{a}}$ & $8.200^{a}$ & $7.767^{b}$ & $7.167^{\mathrm{b}}$ & $6.967^{L}$ & $6.033^{c}$ \\
\hline E & $9.151^{\mathrm{a}}$ & $8.884^{a}$ & $8.600^{\mathrm{a}}$ & $8.333^{\mathrm{a}}$ & $7.933^{b}$ & $7.349^{b}$ & $6.816^{\mathrm{b}}$ & $6.749^{b}$ & $6.283^{b}$ & $5.349^{c}$ \\
\hline L.S.D & 1.589 & & & & & & & & & \\
\hline \multicolumn{11}{|l|}{ Flavor } \\
\hline A & $9.218^{\mathrm{a}}$ & $8.300^{\mathrm{a}}$ & $7.10^{\mathrm{a}}$ & $5.20^{\mathrm{b}}$ & Reject & Reject & Reject & Reject & Reject & Reject \\
\hline B & $9.151^{a}$ & $8.500^{\mathrm{a}}$ & $7.90^{\mathrm{a}}$ & $6.40^{\mathrm{b}}$ & $6.20^{\mathrm{b}}$ & $6.0^{\mathrm{b}}$ & $5.50^{\mathrm{b}}$ & Reject & Reject & Reject \\
\hline C & $9.151^{\mathrm{a}}$ & $8.60^{\mathrm{a}}$ & $8.00^{\mathrm{a}}$ & $7.80^{\mathrm{a}}$ & $7.40^{\mathrm{a}}$ & $6.80^{\mathrm{b}}$ & $6.50^{\mathrm{b}}$ & $5.80^{\mathrm{b}}$ & $5.50^{\mathrm{b}}$ & $5.20^{c}$ \\
\hline D & $9.018^{a}$ & $8.75 \mathrm{I}^{\mathrm{a}}$ & $8.20^{\mathrm{a}}$ & $7.90^{\mathrm{a}}$ & $7.30^{\mathrm{b}}$ & $6.90^{\mathrm{b}}$ & $6.40^{\mathrm{b}}$ & $6.10^{\mathrm{b}}$ & $5.60^{\mathrm{b}}$ & $5.30^{c}$ \\
\hline$E$ & $9.084^{\mathrm{a}}$ & $8.818^{a}$ & $8.40^{\mathrm{a}}$ & $8.00^{\mathrm{a}}$ & $7.50^{\mathrm{a}}$ & $7.10^{\mathrm{b}}$ & $6.70^{\mathrm{b}}$ & $6.20^{\mathrm{b}}$ & $5.80^{\mathrm{b}}$ & $5.50^{c}$ \\
\hline L.S.D & 1.9164 & & & & & & & & & \\
\hline \multicolumn{11}{|l|}{ Texture } \\
\hline A & $9.18 \mathrm{I}^{\mathrm{a}}$ & $8.40^{\mathrm{a}}$ & $6.50^{\mathrm{b}}$ & $5.30^{c}$ & Reject & Reject & Reject & Reject & Reject & Reject \\
\hline B & $9.248^{\mathrm{a}}$ & $8.30^{\mathrm{a}}$ & $7.20^{b}$ & $7.00^{b}$ & $6.50^{\mathrm{b}}$ & $6.20^{\mathrm{b}}$ & $5.40^{c}$ & Reject & Reject & Reject \\
\hline C & $9.115^{\mathrm{a}}$ & $8.40^{\mathrm{a}}$ & $7.90^{\mathrm{a}}$ & $7.60^{\mathrm{a}}$ & $7.40^{\mathrm{b}}$ & $6.90^{\mathrm{b}}$ & $6.30^{\mathrm{b}}$ & $6.00^{b}$ & $5.80^{\mathrm{b}}$ & $5.20^{c}$ \\
\hline D & $9.115^{a}$ & $8.50^{\mathrm{a}}$ & $8.00^{\mathrm{a}}$ & $7.70^{\mathrm{a}}$ & $7.30^{\mathrm{b}}$ & $6.70^{b}$ & $6.40^{\mathrm{b}}$ & $6.20^{\mathrm{b}}$ & $5.90^{\mathrm{b}}$ & $5.40^{c}$ \\
\hline$E$ & $9.115^{a}$ & $8.50^{\mathrm{a}}$ & $8.10^{\mathrm{a}}$ & $7.90^{\mathrm{a}}$ & $7.50^{\mathrm{a}}$ & $7.10^{\mathrm{b}}$ & $6.60^{\mathrm{b}}$ & $6.30^{\mathrm{b}}$ & $6.10^{\mathrm{b}}$ & $5.50^{c}$ \\
\hline L.S.D & 1.7959 & & & & & & & & & \\
\hline \multicolumn{11}{|l|}{ Overall } \\
\hline A & $9.237^{a}$ & $8.500^{\mathrm{a}}$ & $7.200^{\mathrm{b}}$ & $5.400^{c}$ & Reject & Reject & Reject & Reject & Reject & Reject \\
\hline B & $9.171^{\mathrm{a}}$ & $8.500^{\mathrm{a}}$ & $7.900^{\mathrm{a}}$ & $6.500^{\mathrm{b}}$ & $6.600^{\mathrm{b}}$ & $6.400^{b}$ & $5.800^{\mathrm{b}}$ & Reject & Reject & Reject \\
\hline C & $9.17 I^{\mathrm{a}}$ & $8.77 I^{a}$ & $8.300^{\mathrm{a}}$ & $7.900^{\mathrm{a}}$ & $7.600^{\mathrm{a}}$ & $6.900^{\mathrm{b}}$ & $6.500^{\mathrm{b}}$ & $6.100^{\mathrm{b}}$ & $5.900^{\mathrm{b}}$ & $5.400^{c}$ \\
\hline D & $9.237^{a}$ & $8.700^{\mathrm{a}}$ & $8.300^{\mathrm{a}}$ & $7.900^{\mathrm{a}}$ & $7.500^{\mathrm{a}}$ & $7.100^{\mathrm{b}}$ & $6.600^{\mathrm{b}}$ & $6.300^{\mathrm{b}}$ & $6.000^{\mathrm{b}}$ & $5.300^{c}$ \\
\hline$E$ & $9.237^{a}$ & $8.837^{a}$ & $8.400^{\mathrm{a}}$ & $8.00^{\mathrm{a}}$ & $7.700^{\mathrm{a}}$ & $7.200^{b}$ & $6.800^{\mathrm{b}}$ & $6.500^{b}$ & $6.200^{b}$ & $5.400^{c}$ \\
\hline L.S.D & 1.8298 & & & & & & & & & \\
\hline
\end{tabular}

A, air control; $\mathrm{B}$, edible coating; $\mathrm{C}:\left(100 \% \mathrm{Co}_{2}\right)$; D: $\left(50 \% \mathrm{CO}_{2} / 50 \% \mathrm{~N}_{2}\right)$; $\mathrm{E}:\left(70 \% \mathrm{Co}_{2} / 20 \% \mathrm{~N}_{2} / 10 \% \mathrm{O}_{2}\right)$

Mean treatment and storage period showing the same small letters are not significantly difference $(P \leq 0.05)$.

Citation: Hosam Aboul-Anean, Naglaa A El -Senousi, Ghfour SA. Effect of modified atmosphere packaging and edible films on the quality of carp fish patties. J Nutr Health Food Eng. 2018;8(I):14-22. DOI: 10.15406/jnhfe.2018.08.0025I 
Uğur Günşen et al., ${ }^{22}$ this phenomenon causes changes in organoleptic properties of the product, where high percentage of $\mathrm{CO}_{2}$ probably leads to negative effects on other aspects of the product especially on the sensory aspects. Efficiency of carbon dioxide as anti-microorganism mediator is not entire and is relies on the food product properties and the existence of microbial flora Velu et al. ${ }^{2,30}$

\section{Conclusion}

Modified atmosphere packaging and soy protein coated maintained sensory and chemical and microbial quality attributes during storage at $\left(4 \pm 1^{\circ} \mathrm{C}\right)$ of carp fish patties. Results indicated that the best treatments were $70 \% \mathrm{CO}_{2} / 20 \% \mathrm{~N} / 10 \% \mathrm{O}_{2}$ and $\mathrm{CO}_{2}$ at 27 days of storage followed by treatment $50 \% \mathrm{CO}_{2} / 50 \% \mathrm{~N}_{2}$ at 24 days while, edible coating maintained to 18 days of storage. The effect of packing under the average atmosphere and food membranes on the quality of carp patties.

This study was conducted to determine the effect of different concentrations of filling under an average GHG of $\mathrm{CO}_{2}, \mathrm{~N}_{2}$ and $\mathrm{O}_{2}$

a) The coefficients were (100\%) $\mathrm{CO}_{2}$ and $70 \%\left(\mathrm{O}_{2} 10 \%, \mathrm{~N}_{2} 20 \%\right.$, $\mathrm{CO}_{2}$ and $50 \% \mathrm{CO}_{2} 50 \%, \mathrm{~N}_{2}$ ).

b) And (CO 100\%) and cumin oil-bearing food membranes and their effect on quality traits and increased shelf life

c) The thickness of the carp during cold storage at $4^{\circ} \mathrm{C}$ for 27 days of storage and the estimation of the estimates

d) Chemical, microbial and sensory found that the best treatment was a mixture of gases and $\left(\mathrm{CO}_{2} 70 \% \mathrm{O}_{2} 10 \%, \mathrm{~N}_{2} 20 \%\right)$, where the product was kept high for up to 27 days of storage $\left(50 \% \mathrm{CO}_{2}\right.$ $50 \%, \mathrm{~N}_{2}$ ).

Maintained high product quality up to 24days of storage while the $\mathrm{CO}_{2}$ treatment retained $100 \%$ until 21 days while. The natural membranes were kept as high as 18 days of storage compared to control, which lasted only 9days. Therefore, it is recommended to use the packing under an average gas heater, which depends heavily on the type of internal gas as well. Food edible coating, where we recommend using these treatments to preserve the natural and chemical properties. Microbial as well as the nutritional value of the product of the thickness of the carp and encourage the appetite to eat a product in an easy form Use and trading.

\section{Acknowledgements}

None.

\section{Conflict of interest}

The author declares no conflict of interest.

\section{References}

1. Macfadyen G, Ahmed M, Nasr Allah, et al. Value-chain analysis of Egyptian aquaculture. Project report 2011- 54. Malaysia: The World Fish Center; 2011. 84 p.

2. Velu S, Abu Bakar F, Mahyudin NA, et al. Effect of modified atmosphere packaging on microbial flora changes in fishery products. International Food Research Journal. 2013;20(1):17-26.

3. Lee KT. Quality and safety aspects of meat products as affected by various physical manipulation of packaging material. Meat Science. 2010;86(1):138-150.
4. Payap Masniyom. Deterioration and shelf-life extension of fish and fishery products by modified atmosphere packaging. Songklanakarin. $J$ Sci Technol. 2011;33(2):181-192.

5. Kaleemullah S. Food Packaging study material. India: College of Food Science and Technology, Department of Food Engineering; 2002.

6. Maria Monedero, Maria José Fabra, Pau Talens, et al. Effect of calcium and sodium caseinates on physical characteristics of soy protein isolatelipid films. Journal of Food Engineering. 2010;97(2):228-234.

7. Rayner M, Ciolfi V, Maves B, et al. Development and application of soyprotein films to reduce fat intake in deep-fried foods. Journal of Science and Food Agriculture. 2000;80(6):777-782.

8. AMC. Recommended method for the examination of fish and fish products. The Analyst, Analytical Method Committee; 1979. 104:434-439.

9. Kirk RS, Sawyer R. Pearson's composition and analysis of foods. 9th ed. London: Longman Scientific and Technical; 1991. 708 p.

10. Malle P, Tao SH. Rapid quantitative determination of trimethylamine using steam distillation. Journal of Food Protection. 1987;50(9):756760 .

11. Vanderzanthe C, Splittstoesser DF. Compendium of methods for the microbiological examination of foods. USA: APHA; 1992.

12. FAO Manuals of Food Quality Control. Italy: Microbiological Analysis of the United Nations, FAO; 1979.

13. McClain D, Lee WH. Development of USDA-FSIS method for isolation of Listeria monocytogenes from raw meat and poultry. J Assoc off Anal Chem. 1988;71(3):660-664.

14. FDA Bacteriological Analytical Manual. In: Compendium of microbiological methods for the analysis of food and agricultural methods. USA: Association of Official Analytical Chemists, FDA; 2000.

15. Microbiology of Food and Animal Feeding Stuffs-Horizontal Method for the Enumeration of $\beta$-glucuronidase-positive Escherichia coli. Part 2 : Colony-count technique at $44^{\circ} \mathrm{C}$ using 5-bromo-4-chloro-3-indoyl-beta-D-glucuronide. ISO; 2001:16649-16652.

16. DLG. Trepanned Export Prufung Agawer bung Gmb Hamburg. West Germany; 1973.

17. Snedecor GW, Cochran WG. Statistical methods. 7th ed. USA: The Iowa State Univ, Press Amer; 1989. 50 p

18. Aly SSH. The effect of packaging materials and modified atmosphere on the shelf life of meat during cold storage. Egypt; 2001.

19. Hunt MC, Mohan A. Advancement in meat packaging. Canada: Canadian Meat Council; 2008.

20. Soccol MCH, Oetterer M. Use of modified atmosphere in seafood preservation. Brazilian Archives of Biology and Technology. 2003;46(4):569580 .

21. Egyptian organization, standardization the standards of frozen fish number. EOS; 2005.

22. Metin S, Erkan N, Baygar T, et al. Modified atmosphere packaging of fish salad. Fisheries Science. 2002;68:204-209.

23. Goulas AE, Kontominas MG. Combined effect of light salting, modified atmosphere packaging and oregano essential oil on the shelf-life of sea bream (Sparu saurata): biochemical and sensory attributes. Food Chemistry. 2007;100(1):287-296.

24. Uğur Günşen, Ali Özcan, Ali Aydın. Determination of Some Quality Criteria of Cold Storaged Marinated Anchovy under Vacuum and Modified Atmosphere Conditions. Turkish Journal of Fisheries and Aquatic Sciences. 2011;11:233-242. 
25. Lauzon HL, Magnusson H, Sveinsdottir K, et al. Effect of brining, modified atmosphere packaging, and superchilling on the shelf life of cod (Gadus morhua) loins. J Food Sci. 2009;74(6):258-267.

26. Li J, Xie J. Application of super chilling combined with modified atmosphere packaging and preservative on preservation for meat products. Hubei Agricultural Sciences. 2008.

27. Chen $\mathrm{SC}$, Lin $\mathrm{CA}, \mathrm{Fu} \mathrm{AH}$, et al. Inhibition of microbial growth in ready-to-eat food stored at ambient temperature by modified atmosphere packaging. Packaging Technology Science. 2003;16(6):239-247.

28. Arashisar S, Hisar O, Kaya M, et al. Effects of modified atmosphere and vacuum packaging on microbiological and chemical properties of rainbow trout (Oncorynchus mykiss) fillets. Int J Food Microbiol. 2004;97(2):209-214.
29. Lopez-Caballero ME, Goncalves A, Nunes ML. Effect of $\mathrm{CO}_{2} / \mathrm{O}_{2}$ containing modified atmospheres on packed deepwater pink shrimp ( $\mathrm{Pa}$ rapenaeus longirostris). European Food Research and Technology. 2002;214(3):192-197.

30. Goulas AE, Kontominas MG. Effect of salting and smoking-method on the keeping quality of chub mackerel (Scomber japonicus): Biochemical and sensory attributes. Food Chemistry. 2005;93(3):511-520.

31. Ozoğul F, Ozoğul Y. Biogenic amine content and biogenic amine quality indices of sardines (Sardina pilchardus) stored in modified atmosphere packaging and vacuum packaging. Food Chemistry. 2006;99(3):574 578

32. Goulas A, Chouliara I, Nessi E, et al. Microbiological, biochemical and sensory assessment of mussels (Mytilus galloprovincialis) stored under modified atmosphere packaging. J Appl Microbiol. 2005;98(3):752-760. 